\title{
FELINE LEUKEMIAS: FEATURES OF PATHOGENIC CHANGES IN BLOOD
}

\author{
Kostiuk I. A., Zhukova I. A., Liakhovych L. M., Ulyanitskaya A. Yu., \\ Kochevenko E. S., Lonhus N. I., Osman M. S.
}

\author{
Kharkiv State Zooveterinary Academy, Kharkiv, Ukraine, e-mail: innakostiuk2017@gmail.com
}

\begin{abstract}
Summary. Feline viral leukemia is a widespread disease in various countries around the world. According to the data provided by nation-wide data sets, from $3.1 \%$ of cats (in the USA) to $24.5 \%$ (in Thailand) tested positive for FeLV. In Ukraine, there are practically no results of studying this phenomenon. Leukemia is a malignant blood disease. According to various sources, the animals die within 3-4 years, there is also the possibility of recovery, but the greatest danger is the hidden, chronic course, the virus carriers and the unlimited possibility of spreading the virus, both among domestic and among street animals. The latent course and long incubation period of this disease impede timely diagnosis and effective therapeutic measures. Infection of healthy animals can occur as a result of contact with infected animals, during participation in exhibitions, during the breeding of animals, contacts with stray cats. Manifestations of viral leukemia can vary, affecting primarily the work of the immune system. The pathogenic mechanisms of the disease development should be studied in connection with viral damage to bone marrow stem cells and impaired blood formation processes, the development of an immunodeficiency state. The identification of qualitative and quantitative changes in blood cells and the determination of pathogenic mechanisms of disease development are necessary for early diagnosis of the disease and prevention of infection in healthy animals. Detection of specific signs typical for the leukemic blood picture in cats is a necessary part of a comprehensive diagnosis, together with specific studies (PCR, etc.). A blood test is the primary stage of detecting a disease. Specific structural and functional changes, in particular neutrophils, lymphocytes and erythrocytes, allow us to broaden our understanding of the development of symptoms, the course of the disease and possible outcomes
\end{abstract}

Keywords: cat, blood smears, erythrocytes, feline viral leukemia virus, immunodeficiency, lymphocytes, neutrophils, pathogenesis

Feline leukemia virus (FeLV) remains one of the most important infectious diseases of cats globally. It manifests primarily through profound anemia, malignancies, and immunosuppression and infects domestic cats and other species of Felidae (Cotter, 2019). Feline retroviruses are widespread infections of cats (Zolototrubov and Fedosov, 2008; Sulimov, 2004).

Leukemia is a malignancy (cancer) of blood cells. In leukemia, abnormal blood cells are produced in the bone marrow. Usually, leukemia involves the production of abnormal white blood cells - the cells responsible for fighting infection. However, the abnormal cells in leukemia do not function in the same way as normal white blood cells. The leukemia cells continue to grow and divide, eventually crowding out the normal blood cells. The end result is that it becomes difficult for the body to fight infections, control bleeding, and transport oxygen.

$\mathrm{FeLV}$ is a retrovirus in the subfamily Oncovirinae. Other oncoviruses include feline sarcoma virus, mouse leukemia viruses, and two human T-lymphotropic viruses. Although oncogenesis is one of their more dramatic effects, oncoviruses cause many other conditions, including degenerative, proliferative, and immunologic disorders. Studies show that the prevalence of viral leukemia is up to $30 \%$ among urban cats. After the onset of symptoms of a chronic disease, the average life expectancy of animals does not exceed 3-4 years. In the USA, 3.1\% of cats in a large, nation-wide data set tested positive for FeLV in 2010, with increased risk among outdoor cats, unneutered males, and cats with other diseases (particularly respiratory disease, oral disease, and abscession). Seroprevalence surveys of varying statistical power have found rates of positive test results to range from 3.6\% in Germany and Canada to 4.6\% in Egypt and $24.5 \%$ in Thailand. Commercial serological sets were used for the examination of 727 cats kept in large towns of the Czech Republic. FeLV antigen and antibodies to FIV were demonstrated in $96(13.2 \%)$ and 42 (5.8\%) of the animals, respectively (Knotek et al., 1999). Antigens of FeLV were detected in $16.7 \%$ of the sampled cats; $11(64.7 \%)$ of the 17 positive cats were older than one year at the time of testing (Blanco et al., 2009). The prevalence of FIV and FeLV infections in cats in urban settings in Istanbul has been studied (Yilmaz, Ilgaz and Harbour, 2000). The infection of cats with FeLV in the Moscow metropolis was $15.8 \%$ (Gulyukina, 2018). Leukemia of cats is a big problem for nurseries. In nature, FeLV infects domestic cats and a few other Felidae. In the laboratory, cells from a much wider range of species can be infected by some strains of the virus (Turzhanskaya, 2006). For the first time, clinical signs and pathological changes in the body of the Amur tiger, withdrawn from the wild nature, were described (Lyubchenko and Korotkova, 2015).

Leukemia and immunodeficiency as latent virus diseases of cats. To prevent the propagation of these diseases it is recommended to test cats for FeLV and FIV before breeding, hemotransfusion, expositions and moving to another region (Bazhibina and Sokolova, 2010). 
The authors of the article did not find data on the distribution of feline leukemia in Ukraine, but according to own research data from the staff of the Department of Pathological Anatomy and Autopsy at the Kharkov State Zooveterinary Academy, only in 2019 this diagnosis was made in several cases. Photos from the research results are shown in Fig. 1-6.

Pathogenesis: the incubation period can last 4-30 weeks. FeLV-related disorders are numerous and include anemia, neoplasia, immunosuppression, immune-mediated diseases, reproductive problems, enteritis, neurologic dysfunction, and stomatitis. The disease has many different clinical symptoms but none of them are specific. Observation of unsuccessful multicat householders has shown that: some of FeLV-positive cats died, other survived and felt not so bad, some of them had different signs of chronic disease (Nepoklonova et al., 2005). There is a great need for sensitive specific methods of screening and identifying carriers and infected with leukemia cats (FeLV) to control the spread of the virus in the cat population. It is known that the cat leukemia virus has tropism for lymphocytes, enterocytes, macrophages, astrocytes, endotheliocytes, etc. (Polyakova et al., 2017).

But what changes are primary? After oronasal inoculation, the virus first replicates in oropharyngeal lymphoid tissue. From there, virus is carried in blood mononuclear cells to spleen, lymph nodes, epithelial cells of the intestine and bladder, salivary glands, and bone marrow. Virus also appears in secretions and excretions of these tissues and in peripheral blood leukocytes and platelets. Viremia is usually evident 2-4 weeks after infection. Six sequential phases of FeLV infection (i. e. viral replication) were identified:

1) lymphoreticular cells in local lymphoid tissues;

2) circulating lymphocytes and monocytes (early cellassociated viremia);

3) lymphoid germinal cells in lymphoid tissues throughout the body;

4) bone marrow neutrophil and platelet precursor cells and intestinal crypt epithelium;

5) circulating neutrophils and platelets (with establishment of viremia);

6) mucosal and glandular epithelial tissues, with excretion of FeLV (Rojko et al., 1979).

Oncogenesis occurs when FeLV virus inserts into the host cellular genome, either in proximity to an oncogene resulting in activation or directly into the oncogene itself to form a recombinant subgroup virus such as FeLV-B that can induce new neoplastic activity in any cell the recombinant virus enters.

In the blood and saliva, the virus is detected one month after infection. After a few months, the pathogen can be found in the bone marrow, spleen and lymph nodes.

In the pathogenesis of the disease one of two ways can prevail: 1) the development of lymphomas and lymphosarcomas in the different organs; 2) direct malignant lesion of the blood-forming apparatus and, as a result, leukemia.

Lymphoma is the most frequently diagnosed malignancy of cats (Levy and Burling, 2019). In viruspositive cats, the complement concentration in the blood decreases, which leads to immunodeficiency and the development of neoplasias (Turzhanskaya, 2006).

Tumors such as lymphoma and lymphoid leukemia develop in as many as $30 \%$ of cats with progressive FeLV infections. Regressive infections are also implicated in the occurrence of these tumors in the absence of viremia, but cats with progressive infections may face a 60 -fold increased risk of lymphoma development. Most cats with mediastinal, multicentric, or spinal forms of lymphoma are FeLV-positive. However, these forms of lymphoma are becoming less common as the prevalence of FeLV decreases. Karysheva (2002) informs, that in cats, leukemia occurs more often at the age of 1-2 years, and then at the age of 11 years and older, and in almost $90 \%$ of the cases animals fall ill on lymphosarcoma. Fibrosarcomas and quasi-neoplastic disorders such as multiple cartilaginous exostoses (osteochondromatosis) may be FeLV-associated.

Primary leukemias are a type of cancer in which abnormal white blood cells displace normal blood cells. This leads to anemia and a lack of normal white blood cells and platelets. Primary leukemias are uncommon, but they have been reported in cats. Retroviruses (feline leukemia virus and feline immunodeficiency virus) are a cause in some cats. Leukemias are classified as acute (sudden and often severe) or chronic (longterm). Acute leukemias, in which the marrow is filled with immature blood cells, generally respond poorly to chemotherapy. In animals that do respond, remission times are usually short. Chronic leukemias, in which there is greatly increased production of one blood cell line, are less likely to cause anemia and are more responsive to treatment.

Diseases associated with FeLV may affect any organ, and include blood dyscrasias (Little et al., 2012; Coleman et al., 2014).

Blood changes can vary and depend on the stage of the disease and the type of hemopoiesis disorders. So it is reported that, in the changes of blood leukocytosis is observed, significant shift of the leukocyte formula to the left, decrease the number of erythrocytes and a gradual decrease in hematocrit (Galatiuk et al., 2016).

Biometric characteristics of the lymphocytes in cats infected with FeLV and FIV are analyzed in comparison with lymphocytes of healthy cats. AFM-scanning revealed significant differences of morphological and biophysical characteristics of lymphocytes of healthy and infected cats (Krasnikova et al., 2016). In sick animals, leukopenia is observed up to $1.5 \times 10^{9} / 1$, lymphocytosis is up to $99 \%$, in peripheral blood smears the number of mitotic cells reached $4 \%$ (at a rate of up to $0.4 \%$ ) (Zolototrubov, Fedosov and Grebenshchikov, 2005). 


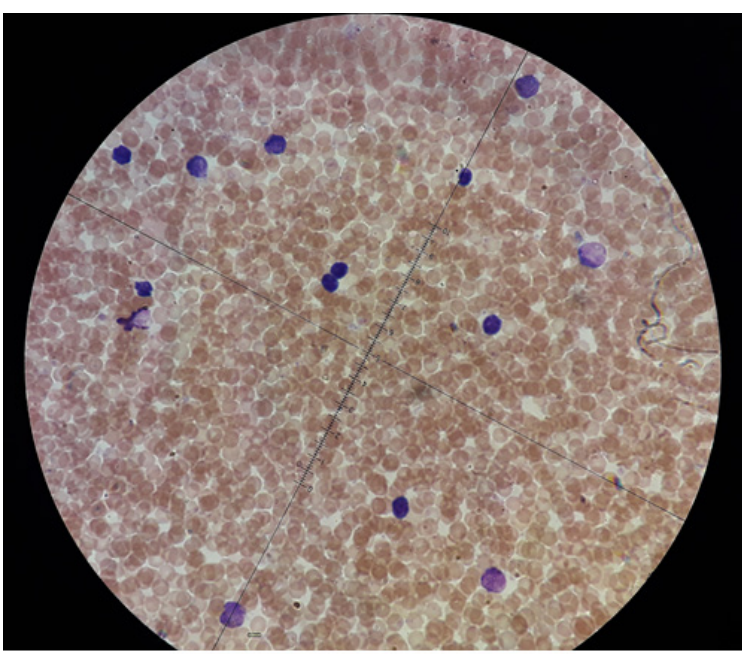

Figure 1. Cat. Blood smear, Pappenheim-Kryukov staining: Acute lymphocytic leukemia

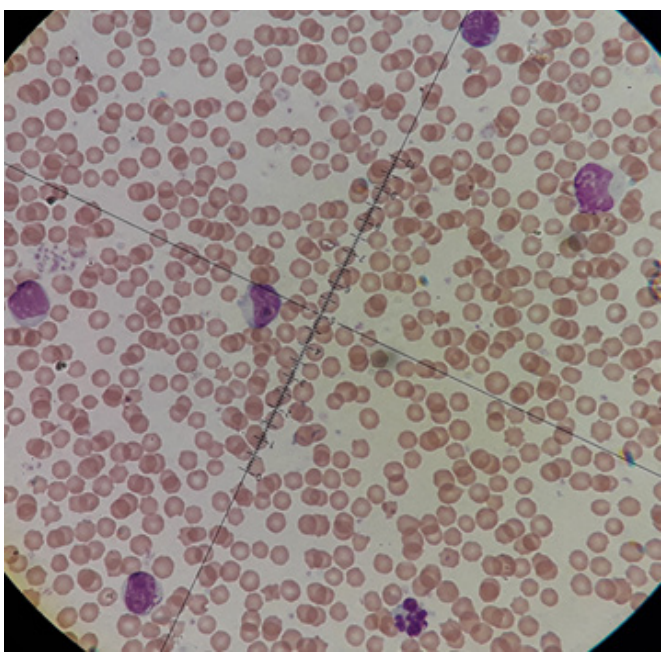

Figure 3. Cat. Blood smear, Romanovsky-Giemsa staining, lymphoblasts

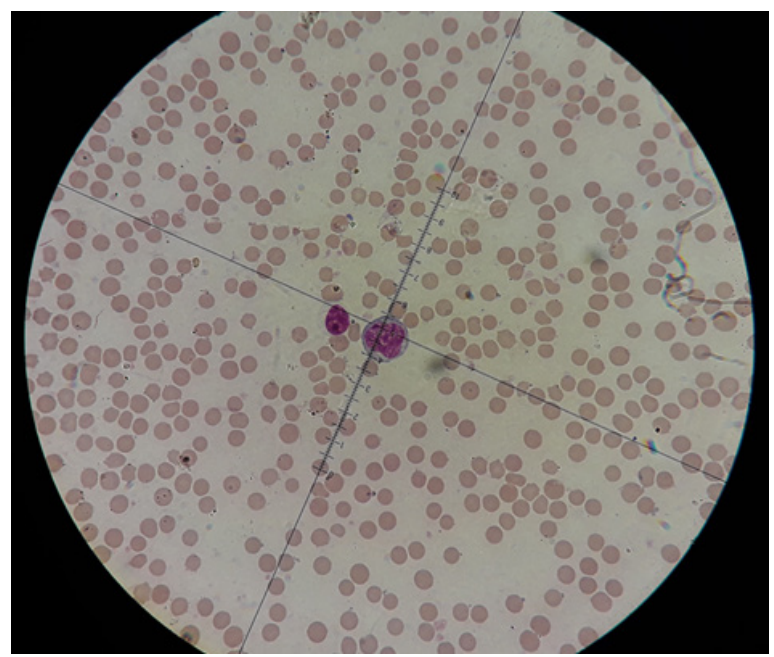

Figure 5. A blood smear of a cat with lymphoma (formation of Heinz bodies in hemolytic anemia)

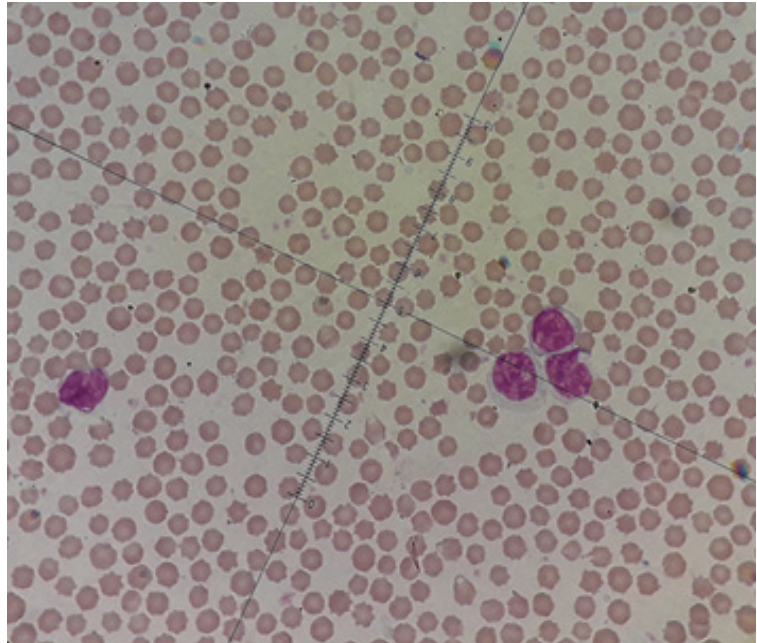

Figure 2. Cat. Blood smear: Acute lymphocytic leukemia, mitotic cells

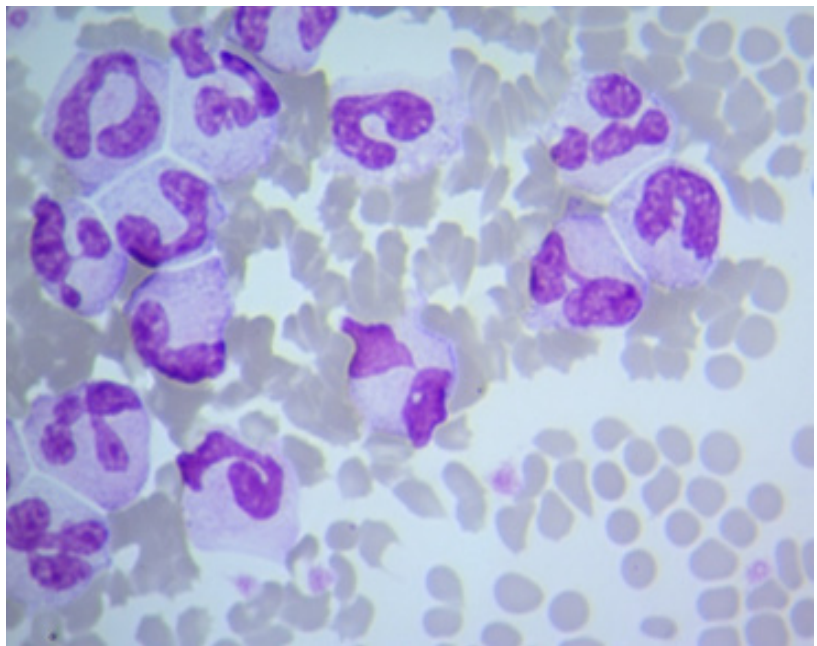

Figure 4. Cat. Giant neutrophils in cat blood in viral leukemia. Disgranulopoiesis

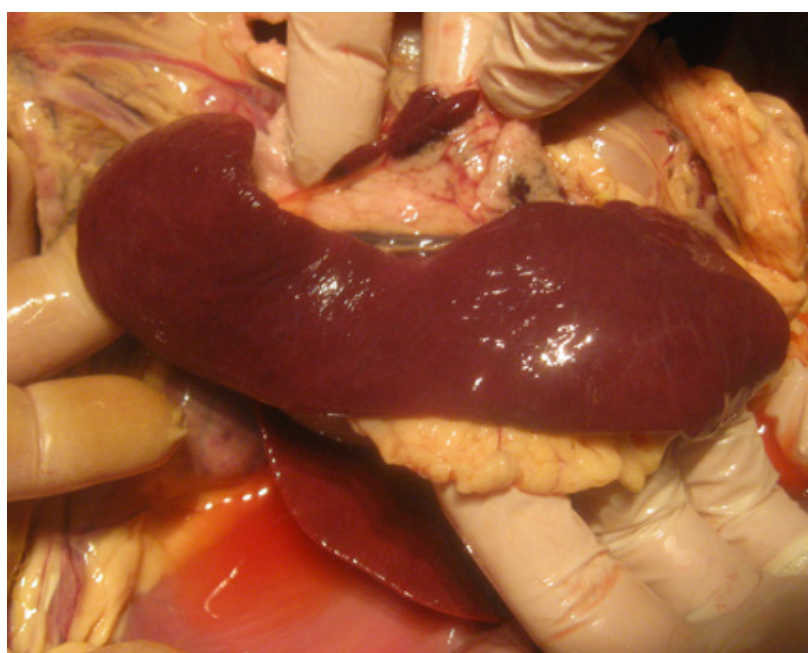

Figure 6. Cat, spleen hyperplasia in leukemia

Figures 1-6. Blood disorders caused by FeLV (all original photo are provided in 2019 by staff of the Department of Pathological Anatomy and Autopsy at the Kharkov State Zooveterinary Academy (Fig. 1-3, 5, 6) and in 2019 (Fig. 4) by Dr. S. V. Shishkanova (2012) 
In viral leukemia in cats (Polyakova et al., 2017), lymphocytes can remain within the normal range, as they can either increase pathologically (24\% of the entire sample) or decrease ( $29 \%$ of the entire sample).

Leukemia is characterized by the neoplastic proliferation of hematopoietic cells originating in the bone marrow, including neutrophils, basophils, eosinophils, monocytes, lymphocytes, megakaryocytes, and erythrocytes. Feline leukemias are strongly associated with FeLV infection and typically involve neoplastic cells circulating in the blood. Lymphoid leukemias are further classified as acute and chronic. Acute lymphocytic leukemia (Fig. 1-3) is characterized by lymphoblasts circulating in the blood, whereas chronic lymphocytic leukemias have an increased number of circulating lymphocytes with mature morphology.

In animals, there are suppressive disorders of the bone marrow and hematological malignant tumors (Linenberger and Abkowitz, 1995).

Bone marrow failure can lead to nonregenerative anemia and a reduction in the number of all types of blood cells - red, white, and platelets. With widespread marrow involvement, white blood cells are affected first, followed by platelets, and finally red blood cells (Nikitin, 1949; Reagan, Sanders and DeNicola, 2008; Lugovskaya and Pochtar, 2011). Myeloid or myelogenous leukemias are made up of cells that arise from myeloid cells, while lymphoid leukemias arise from lymphoid cells. Knowing the type of cell involved in leukemia is important in choosing the appropriate treatment.

Myelodysplasia (also called myelodysplastic syndrome) is a bone marrow disorder in which growth and maturation of blood-forming cells in the bone marrow is defective. This leads to nonregenerative anemia or shortages of white blood cells or platelets. It is considered a preleukemic syndrome (occurring before leukemia fully develops). Myelodysplasia commonly occurs in cats with feline leukemia but can also occur as the result of other tumors, drug therapy, or mutations in stem cells. Survival rates vary because myelodysplasia can progress to leukemia. Many animals with this state die from infection, bleeding, or anemia.

Myelophthisis is a direct effect of tumors on the bone marrow - replacement of bone marrow spaces with cells that suppress the proliferation of normal hematopoietic cells. When myelophthisis is characteristic of leukemia, disseminated lymphomas (Fig. 2), non-regenerative normocytic normochromic anemia are typical, often in combination with thrombocytopenia and leukopenia.

In the presence of such changes in the clinical analysis of blood, the most important step is the assessment of a venous blood smear for the presence of atypical cells. A cyto- or histological analysis of the bone marrow is also necessary. Fig. 2 shows a bone marrow biopsy from a cat with disseminated lymphoma - a total replacement of bone marrow spaces with large tumor lymphoid cells is noted (hematoxylin-eosin staining, $\times 400$ ). Anemia occurs in $1 / 2-1 / 3$ cats with viral leukemia.

The anemia caused by FeLV is typically nonregenerative and normochromic. Less commonly, macrocytosis or regenerative hemolytic anemia is seen in only $10 \%$ of FeLV-induced anemia cases. A blood smear of a cat with leukemia was presented according to the results of own research made by the staff of the Department of Pathological Anatomy and Autopsy. Changes in erythrocytes, anisocytosis and the formation of Heinz bodies during hemolytic anemia are shown (Fig. 5) and hyperplasia of the spleen (Fig. 6). The cause of nonregenerative anemia is usually bone marrow suppression due to viral infection of the hematopoietic stem cells and the supporting stromal cells. Platelet dysfunction, thrombocytopenia, and neutropenia are possible sequelae as well. Tumor-associated anemia can be an important adverse prognostic factor that should be considered when planning therapy targeting the underlying disease (Lisitskaya, 2016). In cats with lymphoma, oxidative red blood cell damage is described with the development of anemia with Heinz's bodies (Fig. 3). A group of researchers reports, at the same time, in animals with pronounced changes in the absolute number of lymphocytes, the hematocrit and the absolute number of red blood cells are often decreased slightly (Polyakova et al., 2017).

Dysgranulopoiesis is characterized by a decrease in the number of progenitor cells in the bone marrow or impaired cell maturation. When conducting a clinical analysis of blood, atypical, immature, giant cells are found in smears (Fig. 4). Giant neutrophils result from missing one of the cell divisions in the bone marrow. These cells can have both a normal morphology of the nucleus, and hyposegmented nuclei. Giant neutrophils always indicate severe neutrophil toxicity. The appearance of giant neutrophils in the blood (Fig. 4) is a characteristic of severe inflammatory processes or disgranulopoiesis, in particular, in viral leukemia in cats (Shishkanova, 2012). The acute stage of FeLV infection occurring 2-6 weeks after infection is rarely detected but typically characterized by mild fever, malaise, lymphadenopathy, and blood cytopenias. Cats unable to mount an adequate immune response become persistently viremic and develop a progressive infection, often leading to fatal disease. Viral suppression of immunity leads to the fact that any infectious disease becomes deadly for an animal. The study of questions of therapy of retrovirus infections is one of major problems of modern medicine (Zolototrubov et al., 2005).

The immunosuppression caused by FeLV creates increased susceptibility to bacterial, fungal, protozoal, and viral infections. Numbers of neutrophils and lymphocytes in the peripheral blood of affected cats may be reduced, 
and those cells that are present may be dysfunctional. Many FeLV-positive cats have low blood concentrations of complement; this contributes to FeLV-associated immunodeficiency and oncogenicity, because complement is vital for some forms of antibody-mediated tumor cell lysis.

A deficiency in phagocytosis can be caused by a low number of phagocytes in the blood or by a defect in their ability to act normally. The deficiency increases susceptibility to bacterial infections of the skin, respiratory system, and gastrointestinal tract. Stomatitis (Fig. 5) is more classically associated with FIV infection, but FeLV infection can also predispose cats to chronic ulcerative proliferative gingivostomatitis. Clinical sequelae include pain, anorexia, and tooth loss. An immune-mediated mechanism is likely, particularly in combination with coinfections such as feline calicivirus.

Immune complexes formed in the presence of moderate antigen excess can cause systemic vasculitis, glomerulonephritis, polyarthritis, and a variety of other immune disorders. In FeLV-infected cats formation of immune complexes under conditions, in which FeLV antigens are abundant and anti-FeLV IgG antibodies are sparse, leads to the development of immune-mediated diseases.
Coinfection with FeLV and feline panleukopenia virus (FPV) has been implicated in feline panleukopenia-like syndrome (FPLS), which is also termed FeLV-associated enteritis. FPLS resembles feline panleukopenia both clinically and histopathologically and is characterized clinically by progressive anorexia, depression, vomiting, hemorrhagic diarrhea, weight loss, gingivitis, oral ulceration, severe neutropenia, and septicemia (MacPete, 2014; Powers et al., 2018). FPV antigen is inconsistently present on diagnostic testing in these cases, and the pathogenesis and exact role of each virus in the development of this syndrome are incompletely understood.

Conclusions. Pathogenetic features of blood changes in viral leukemia of cats manifest as a result of damage to the cells of the hematopoietic apparatus. When the myeloid form in the peripheral blood among atypical cells, giant immature neutrophils are predominantly detected. Lymphoid form can be manifested by lymphocytosis.

The result of the primary violation of blood formation is anemia and immunodeficiency, which is manifested by a decrease in antitumor protection, a violation of the barrier mechanisms of mucous membranes and the skin and, as a consequence, secondary infection and the occurrence of tumors in various organs.

\section{References}

Bazhibina, E. B. and Sokolova, Yu. B. (2010) 'Leukemia and immunodeficiency as latent virus diseases of cats' [Leykemiya i immunodefitsit - skrytye virusnye infektsii koshek], Russian Veterinary Journal. Small Domestic and Wild Animals [Rossiyskiy veterinarnyy zhurnal. Melkie domashnie i dikie zhivotnye], 1, pp. 14-17. Available at: https://www.elibrary.ru/item.asp?id= 13294322; http://logospressmsk.ru/data/vet/mdg/pdf_mdg/pdf _mdg_2010/mdg-nomer-1-2010.pdf. [in Russian].

Blanco, K., Prendas, J., Cortes, R., Jimenez, C. and Dolz, G. (2009) 'Seroprevalence of viral infections in domestic cats in Costa Rice', Journal of Veterinary Medical Science, 71(5), pp. 661663. doi: 10.1292/jvms.71.661.

Coleman, J. K., Pu, R., Martin, M. M., Noon-Song, E. N., Zwijnenberg, R. and Yamamoto, J. K. (2014) 'Feline immunodeficiency virus (FIV) vaccine efficacy and FIV neutralizing antibodies', Vaccine, 32(6), pp.746-754. doi: 10.1016/j.vaccine.2013.05.024.

Cotter, S. M. (2019) Introduction to Blood Disorders of Cats. Available at: https://www.merckvetmanual.com/cat-owners/b lood-disorders-of-cats/introduction-to-blood-disorders-of-cats (Accessed 8 April 2019).

Galatiuk, O. Ye., Peredera, O. O, Lavrinenko, I. V and Zhernosik, I. A. (2016) Infectious Diseases of Cats [Infektsiini khvoroby kotiv]. Zhytomyr: Polissia. Available at: http://ir.znau. edu.ua/handle/123456789/5644. [in Ukrainian].

Gulyukina, I. A. (2018) 'Feline leukemia in modern metropolis' [Leykoz koshek $\mathrm{v}$ usloviyakh sovremennogo megapolisa], Russian Veterinary Journal [Rossiyskiy veterinarnyy zhurnal], 5, pp. 14-17. doi: 10.32416/article_5d1caf6656cdb2. 21305129. [in Russian].
Karysheva, A. F. (2002) Special Epizootology [Spetsialna epizootolohiia]. Kyiv: Vyshcha osvita. ISBN 966808100. [in Ukrainian].

Knotek, Z., Hájková, P., Svoboda, M., Toman, M. and Raška, V. (1999) 'Epidemiology of Feline leukaemia and Feline immunodeficiency virus infections in the Czech Republic', Journal of Veterinary Medicine, Series B, 46(10), pp. 665-671. doi: 10.1046/j.1439-0450.1999.00302.x.

Krasnikova, E. S., Stolbovskaya, O. V., Kostishko, B. B., Artemiev, D. A. and Faust, E. A. (2016) 'The study of the influence of FIV and FELV-infection on biometric characteristics of cat's lymphocytes' [Izuchenie vliyaniya FIV- i FELV-infektsii na biometricheskie kharakteristiki limfotsitov koshek], The Agrarian Scientific Journal [Agrarnyy nauchnyy zhurnal], 11, pp. 21-26. Available at: https://www.elibrary.ru/ item.asp?id=27378294. [in Russian].

Levy, J. K. and Burling, A. (2019) Feline Leukemia Virus and Related Diseases in Cats - Overview (Feline Lymphoma and Leukemia, Lymphosarcoma). Available at: https://www.merckvet manual.com/generalized-conditions/feline-leukemia-virus-and -related-diseases/feline-leukemia-virus-and-related-diseases-in -cats-overview (Accessed 8 April 2019).

Linenberger, M. L. and Abkowitz, J. L. 'Haematological disorders associated with Feline retrovirus infections', Baillière's Clinical Haematology, 8(1), pp. 73-112. doi: 10.1016/S0950-3536(05)80233-1.

Lisitskaya, K. (2016) 'Anemia in patients with tumor diseases: From mechanisms to diagnosis and treatment. Interesting clinical cases' [Anemiya u patsientov s opukholevymi zabolevaniyami: ot mekhanizmov k diagnostike 
i lecheniyu. Interesnye klinicheskie sluchai], Modern Veterinary Medicine [Sovremennaya veterinarnaya meditsina], 2, pp. 34-38. Available at: https://zooinform.ru/vete/articles/anemiya-u-pats ientov-s-opukholevymi-zabolevaniyami-ot-mekhanizmov-k-di agnostike-i-lecheniyu/. [in Russian].

Little, S., Bienzle, D., Carioto, L., Chisholm, H., O’Brien, E. and Scherk, M. (2012) 'Feline leukemia and Feline immunodeficiency virus in Canada - A reply', The Canadian Veterinary Journal, 53(1), pp. 10. PMCID: PMC3239142.

Lugovskaya, S. A. and Pochtar', M. E. (2011) Hematological Atlas [Gematologicheskiy atlas]. $3^{\text {rd }}$ ed. Moscow; Tver: Triada. ISBN 9785724915212. [in Russian].

Lyubchenko, E. N. and Korotkova, I. P. (2015) 'Pathomorfological changes in the wild Amur tiger with Lymphoma' [Patomorfologicheskie izmeneniya u dikogo amurskogo tigra pri limfome], The Bulletin of the Krasnoyarsk State Agrarian University [Vestnik Krasnoyarskogo gosudarstvennogo agrarnogo universiteta], 12, pp. 251-254. Available at: https://www.elibrary. ru/item.asp?id=25054310. [in Russian].

MacPete, R. (2014) Feline Leukemia Virus (FeLV). Available at: http://www.pethealthnetwork.com/cat-health/cat-diseases-co nditions-a-z/feline-leukemia-virus-felv (Accessed 8 April 2019).

Nepoklonova, I. V., Lunina, N. A., Tkachov, A. V. and Loginov, N. V. (2005) Feline Leukemia: Features of Current of Infectious Process [Virusnaya leykemiya koshek: osobennosti techeniya infektsionnogo protsessa]. Available at: http://webmvc. com/show/show.php?sec $=4 \&$ art $=8$. [in Russian] .

Nikitin, V. N. (1949) Atlas of Blood Cells of Agricultural and Laboratory Animals [Atlas kletok krovi sel'skokhozyaystvennykh $i$ laboratornykh zhivotnykh]. Moscow: Sel'khozgiz. [in Russian].

Polyakova, I. V., Shabeykin, A. A., $\quad$ Lakhtyukhov, S. V., Gulyukina, I. A., Komina, A. K., Drozdova, E. I. and Zaberezhny, A. D. (2017) 'The incidence of detecting the domestic cats' leukemia virus in Moscow' [Intsidentnost' vyyavleniya virusa leykoza u domashnikh koshek v Moskve], Russian Journal of Agricultural and Socio-Economic Sciences, 71, pp. 551-562. doi: 10.18551/rjoas.2017-11.73. [in Russian].

Powers, J. A., Chiu, E. S., Kraberger, S. J., Roelke-Parker, M., Lowery, I., Erbeck, K., Troyer, R., Carver, S. and VandeWoude, S. (2018) 'Feline leukemia virus (FeLV) disease outcomes in a domestic cat breeding colony: Relationship to endogenous FeLV and other chronic viral infections', Journal of Virology, 92(18), pp. e00649-18. doi: 10.1128/JVI.00649-18.
Reagan, W. J., Sanders, T. G. and DeNicola, D. B. (2008) Veterinary Hematology: Atlas of Common Domestic Species [Atlas veterinarnoy gematologii]. Moscow: Akvarium. ISBN 9785984359306. [in Russian].

Rojko, J. L., Hoover, E. A., Mathes, L. E., Olsen, R. G. and Schaller, J. P. (1979) 'Pathogenesis of experimental Feline leukemia virus infection', JNCI: Journal of the National Cancer Institute, 63(3), pp. 759-768. doi: 10.1093/jnci/63.3.759.

Shishkanova, S. V. (2012) 'Diagnostic value of changes in the morphology of leukocytes' [Diagnosticheskoe znachenie izmeneniya morfologii leykotsitov], Veterinary Petersburg [Veterinarnyy Peterburg], 5. Available at: https://www.spbvet. info/arh/detail.php?ID=335. [in Russian].

Sulimov, A. A. (2004) Viral Diseases of Cats [Virusnye bolezni koshek]. Moscow: KolosS. ISBN 5953202555. [in Russian].

Turzhanskaya, N. M. (2006) 'Feline leukemia virus and accompanying diseases' [Virus leykemii koshek $i$ soputstvuyushchiye zabolevaniya], Russian Veterinary Journal. Small Domestic and Wild Animals [Rossiyskiy veterinarnyy zhurnal. Melkie domashnie i dikie zhivotnye], 1, pp.40-43. Available at: https://www.elibrary.ru/item.asp?id=12887896; http://logospressmsk.ru/data/vet/mdg/pdf_mdg/pdf_mdg_200 6/mdg-nomer-1-2006.pdf. [in Russian].

Yilmaz, H., Ilgaz, A. and Harbour, D. (2000) 'Prevalence of FIV and FELV infections in cats in Istanbul', Journal of Feline Medicine and Surgery, 2(1), pp. 69-70. doi: 10.1053/jfms.2000. 0066.

Zolototrubov, A. P. and Fedosov, D. V. (2008) 'Radiographic method in diagnostics of retroviruses-infected cats' [Rentgenologicheskiy metod $\mathrm{v}$ diagnostike retrovirusnykh infektsiy koshek], Veterinary Pathology [Veterinarnaya patologiya], 4, pp. 83-85. Available at: https://www.elibrary.ru/ item.asp?id=16825303. [in Russian].

Zolototrubov, A. P., Fedosov, D. V. and Grebenshchikov, A. V. (2005) 'Morphological changes in the organs and tissues of cats infected with leukemia virus' [Morfologicheskie izmeneniya $\mathrm{v}$ organakh i tkanyakh koshek infitsirovannykh virusom leykoza], Practician [Praktik], 9-10, pp. 74-79. [in Russian].

Zolototrubov, A. P., Fedosov, D. V., Vostroilova, G. A. and Zharkoy, B. L. (2005) New in Therapy of the Cat Leukemia [Novoye $v$ terapii leykoza koshek]. Available at: http://webmvc. $\mathrm{com} /$ show/show.php?sec $=4 \& \operatorname{art}=33$. [in Russian] . 